\title{
The role of market uncertainty in fostering innovation and green supply chain management on the performance of tourism SMEs
}

\author{
Elza Syarief $^{a^{*}}$
}

${ }^{a}$ Universitas Internasional Batam, Indonesia

\begin{tabular}{l}
\hline C H R O N I C L E \\
\hline Article history: \\
Received January 27, 2021 \\
Received in revised format \\
January, 28, 2021 \\
Accepted May 202021 \\
Available online \\
May 202021 \\
\hline Keywords: \\
Supply Chain Management \\
Market Uncertainty \\
Covid-19 \\
Innovation \\
Green Supply Chain Management \\
SME Performance
\end{tabular}

\section{Introduction}

Since Covid-19 was declared a pandemic, many sectors of the domestic and global economy have been affected. Various countries have implemented lockdown policies to reduce the impact of the spread of the Covid-19 virus. In addition to creating a global health crisis, efforts to suppress and mitigate the Covid-19 pandemic have also caused strong disruption to the international trade order. From the supply side, lockdown and working from home policies have resulted in a reduction in the workforce involved in production activities (Safitri, 2020). With the existence of the policy made by the government, of course it also has an impact on MSME actors (Micro, Small and Medium Enterprises) and even the impact of the pandemic is most felt in the micro, small and medium enterprises (MSME) sector. In Indonesia, the Ministry of Cooperatives and Small and Medium Enterprises (Kemenkop UKM) reported that in 2018, the number of MSMEs in Indonesia was around 64,194,057 units, with an absorption capacity of 116,978,631 total workforces. This figure is equivalent to $99 \%$ of the total business units in Indonesia, with the percentage of labor absorption in the economic sector equivalent to $97 \%$. Meanwhile, the remaining 3 percent is divided into large industrial sectors. Furthermore, Syamsudin (2020) stated that $56 \%$ of MSMEs claimed to have experienced a decrease in sales turnover due to the Covid-19 pandemic, $22 \%$ experienced difficulties in obtaining financing/credit, $15 \%$ experienced problems in the distribution of goods, and the remaining 4\% reported difficulty getting raw materials. Of all the MSMEs recorded in this research, the composition of MSMEs engaged in the micro industry is $87.4 \%$. There are several MSME business fields that are the most affected, namely

* Corresponding author

E-mail address: esyarief.uib@gmail.com (E. Syarief)

C 2021 by the authors; licensee Growing Science. doi: $10.5267 /$ j.uscm.2021.5.009

\begin{abstract}
This research was conducted to examine the extent to which market uncertainty can encourage market players, especially SMEs, to exploit innovation and environmentally friendly orientation this study is proxied by the Covid-19 pandemic, has great potential to reduce performance and disrupt production and distribution lines as well as consumer demand. This encourages affected to maintain their performance with product innovation, and minimize the use of non(SME) producing tourism souvenirs in Yogyakarta, Indonesia. Using the analysis technique of Structural Equation Modeling (SEM) with 150 respondents, the findings indicate that market and product reorientation. Specifically, the results show that there is a positive and significant etween innovation and green orientation on SME performance, and the mediating effect of market uncertainty to increase marketing innovation and environmentally friendly
orientation. These findings theoretically contribute to explaining the relationship between supply chain management in the context of market uncertainty. In practical terms, this study confirms the need for support by stakeholders to support limited domestic
protocols, as well as digitalization of marketing for tourism SMEs.
\end{abstract}

(C) 2021 by the authors; license Growing Science, Canada. 
accommodation, tourism, and food and drink providers, wholesale and retail trade, as well as motorbike repair and transportation and trade (Rosita, 2020). Although the COVID-19 pandemic has raised several problems for MSME players, on the other hand, there are opportunities for innovation in marketing and creating environmentally friendly products. MSME players can take advantage of information and communication technology, considering that electronic commerce in 2020 will reach US \$ 130 billion. Electronic trading transactions drastically increased during the COVID-19 pandemic (Amri, 2020). So far, MSMEs have proven their ability to withstand difficult economic situations. Most of the MSMEs have not had direct contact with the domestic financial sector, let alone global. This situation has made MSMEs more able to survive than large-scale companies against the global financial crisis. MSMEs have an important role in the national economy in various countries, but economically they are more vulnerable to economic shocks from pandemics originating from the supply and demand side (Kementerian PPN/Bappenas, 2020). In this context, SMEs also have initiatives to create focused and effective strategies to accelerate performance recovery through marketing innovations and green supply chain management.

\section{Literature Review and Hypothesis}

\subsection{Supply Chain Management (SCM)}

According to Render and Heizer (2005), supply chain management is all the activities of procuring materials and services, converting semi-finished goods into final products, as well as the delivery process to customers. All these activities include purchasing, outsourcing, plus other functions that are important to the relationship between suppliers and distributors. Outsourcing is an effort to obtain a product or service that is usually or is part of an organization from an outside supplier. According to Wright et al. (2009), there are 5 basic components of Supply Chain Management (SCM), namely planning, source of goods, manufacturing, delivery and return. Planning is the initial success of supply chain management and is in the process of determining the strategy required for supply chain management. The main objective of the strategy formulation process is to ensure efficiency and cost effectiveness as well as ensuring the quality of the resulting product reaches consumers. In terms of source of goods, the Company must choose a supplier of raw materials that is flexible and able to support the production process being carried out. Therefore, supply chain management managers must be able to set prices, manage shipments and process raw material payments and maintain and improve business relationships with suppliers. Manufacturing is conducted where SCM managers prepare a schedule of activities required in the production process, product testing, packaging, and work productivity. In regard to delivery, the Company fulfills orders from consumer demand, manages warehouse networks, stores, selects distributors to deliver products to consumers and manages the payment system, while return is about SCM planning must create a flexible and responsive network for defective products and establish a customer complaint service that has problems with products that have been delivered to consumers. Thus, companies should always make reports on their business performance regularly. So that company leaders can find out changes in business performance that have been carried out in accordance with the initial goals of the SCM that have been set. Supply Chain Management (SCM) affects financial performance in three areas, namely: profitability, liquidity and productivity, where the proxy for the Supply Chain Ratio is built from two financial ratios, namely cash generation and asset efficiency measures (Ellinger et al., 2011).

According to Gitman and Zutter (2012) companies achieve their mission through three competitive strategies. First is competing on differentiation. Differentiation relates to the presentation of something unique and different. The opportunity for a company to create uniqueness can be done in all company activities. Differentiation has different physical characteristics and service attributes that include everything about the product or service that affects the value those consumers get from it. The competitive strategy in differentiation in this study can be measured using the price premium capability indicator. Second, competing on cost. Low-cost leadership means achieving the maximum value the customer wants. This requires testing and judgment from operations management with a great deal of effort to lower costs and still meet customer expected value. A low-cost strategy does not mean that the value or quality of goods is low. The costcompetitive strategy in this study can be measured using the Asset Utilization Efficiency indicator. Third, competing in response. Competing in response is the aggregate value associated with developing and delivering goods on time, reliable scheduling, and flexible performance. Flexible response can be thought of as being able to meet changes in a market where design updates and volume fluctuations occur.

\subsection{The Relationship between Innovation and Performance}

Small business is a part of microeconomics which is expected to be able to improve the people's standard of living. MSME activities in the midst of the Covid19 pandemic are new ventures that must be managed properly and supported by innovation and creativity of the products they produce to have competitiveness (Rosmadi, 2021). Hadiyati (2011), Larsen and Lewis (2007), and Keeh et al. (2007) argue that small industrial activities (MSMEs) can develop and achieve their goals with innovation and creativity in their production results. The results of empirical research conducted by Satria (2011), Darwanto (2013), and Yunal (2013) note that innovation and creativity are very helpful and have a significant effect on the development of small businesses. 
The intensity of competition and market uncertainty can encourage companies to strive for high innovation in order to gain a sustainable competitive advantage over its competitors because it can produce optimal marketing performance (Sherlin, 2016). Innovation comes from creativity which is defined as the ability to imagine and generate new ideas by combining, changing or applying existing ideas in ways that have not been thought of before. Creative ideas which are then processed through several stages to produce a product or service or business model are called innovation (Dama \& Ogi, 2018). The success of a product will boil down to its marketing performance, and from here a product will be considered by consumers, whether the product has differences and advantages over other products from similar competitors (Wulandari, 2012). In the context of uncertainty, Zhu \& Sarkis (2007) stated that green purchasing is more driven by market demand (Priyono, 2009).

\section{$\mathbf{H}_{1}$. There is a positive and significant relationship between innovation and market uncertainty in the tourism SME sector.}

Suendro (2010) shows that product innovation can be enhanced by improving customer orientation, competitor orientation and cross-functional coordination. Furthermore, higher product innovation will affect marketing performance and further increase sustainable competitive advantage. Performance is a description of the level of adjustment in the implementation of an activity in realizing the goals, objectives, mission and vision of the company as stated in the strategic planning of a company (D'Avanzo et al., 2003). According to Sudiyatno \& Puspitasari (2010), company performance can be measured by Tobin's Q as an indicator of company performance from an investment perspective, where company performance as measured using Tobin's' $Q$ is a measure of market assessment. Tobin's Q is an indicator for measuring company performance, especially regarding company value, which shows management's performance in managing company assets. Tobin's Q value describes a condition of investment opportunities that the company has or the company's potential for growth. Dama \& Ogi (2018) show that innovation partially has a significant effect on performance. Innovation must be carried out in a sustainable manner by the company because it is a fundamental requirement in order to be able to create product advantages in competition. Efforts to innovate products are an important function of the management of a company because product innovation can determine a quality marketing performance (Nasir, 2017).

\section{H2. There is a positive and significant relationship between innovations in the performance of the tourism SME sector.}

\subsection{Green Supply Chain Management and Performance}

Strategy is a competitive tool that companies need to have, which requires strong and accurate planning, coordination, supervision and evaluation so as to create a competitive advantage for the company (Le Roy \& Czakon, 2016). The implementation of strategy at the business level is a job that requires a big challenge because often the application of this business strategy is unable to keep up with the expected goals (Wheelen et al., 2017). Therefore, to achieve organizational success, an important thing that needs to be considered for managerial purposes is to implement a good strategy, where managerial duties in implementing and implementing this choice of strategy require an assessment to develop the needs for organizational capabilities and the achievement of targeted goals (Chang et al., 2015). Younis, Sundarakani, and Vel (2016), Zhu et al. (2008), Laari et al. (2016), Zhu et al. (2017), the positive influence of the GSCM variable on environmental performance means that companies implementing the GSCM concept have a high level of environmental performance than companies that do not apply the GSCM concept.

\section{H3. There is a positive and significant relationship between green supply chain management and market uncertainty in the tourism SME sector.}

In addition, company performance can be seen from its profitability, rate of return on investment (ROI), the company's main achievements, growth, innovation and rate of return on assets (ROA/ROE) (Mulyadi, 2001). In this case, company performance as measured by ROA/ROE is a measure of the company's operational performance (Sudiyatno \& Puspitasari, 2010). Meanwhile, profitability is intended to determine the company's ability to generate profits and to find out how far the company is managed efficiently and effectively, so that from managers' perceptions of company profitability it can be a good measure of performance (Irham, 2011). Market orientation has an equally important role and can contribute to improving company performance (Hatani, 2000). GSCM is a guideline for all factors and all elements in the supply chain in paying attention to the environment or not causing harmful impacts on the environment (Setiawan et al., 2011). The results of research regarding the application of GSCM have an effect on improving environmental performance, previous research has been carried out (Rakhmawati et al., 2019). Ninlawan et al. (2010) refer to environmentally friendly manufacturing in a production process that uses efficient input, less pollution, and low harm to the environment (Savita et al., 2016, Stefanelli et al., 2014).

\section{H4. There is a positive and significant relationship with green supply chain management on the performance of the tourism SME sector.}

\subsection{Market Uncertainty and Performance}

Business competition in developments in the era of globalization requires companies to be able to behave and act quickly and appropriately in facing competition in a business environment that moves very dynamically and is full of uncertainty 
(Suendro, 2010). Performance measurement needs to be done to find out whether during the implementation of the performance against the deviation from the predetermined plan, or whether the performance can be carried out according to the specified time schedule, or whether the performance results have been achieved as expected. Accurate performance measurement according to Wibowo (2014) can be done by ensuring that the requirements desired by customers have been met; striving for performance standards to create comparisons, maintaining distance for people to monitor performance levels, defining the importance of quality issues and determining what needs to be priority attention, avoiding the consequences of low quality, considering the use of resources and seeking feedback to encourage improvement efforts.

\section{H5. Market uncertainty has a negative and significant effect on the performance of SMEs.}

\section{Method}

This research was conducted with a quantitative approach with the research location located in the city of Yogyakarta, Indonesia. The populations in this study were all medium-sized business actors in the tourism sector who specifically produced souvenirs and fashion, totaling 155 business actors. The choice of this type of business is because tourism is one of the sectors most affected by market uncertainty and consumer demand due to Covid-19. In addition, the types of businesses in this field in their operations generate waste that varies in shape, quantity and type, so that these types of businesses have a high chance of environmental pollution. To collect data, the questionnaire as an instrument was distributed to respondents, namely owners or managers of tourism sector companies that produce souvenirs such as fashion. In this study, the measurement of the GSCM variable is based on the empirical study of Rakhmawati et al. (2019) with a green production indicator which is defined as an environmentally friendly manufacturing process, starting from considering the risk reduction and environmental impact starting from planning and operation (Fortuna et al., 2014), while green purchasing items include: Low electricity usage, low fuel consumption, the use of food or beverage raw materials for safe production, the use of safe food coloring or beverage materials, as well as the management of residual production waste. Green manufacturing refers to a production process that uses input that is efficient, less polluting, and is less harmful to the environment. The analytical tool used is Structural Equation Modeling (SEM).

\section{Results}

The findings show that all variables are reliable and the items used are valid. In detail, the test results as shown in Table 1 show that the $\lambda$ values of the 2 innovation indicators are 0.656 and 1,000 , with the AVE and C.R values for the innovation variable being 0.715 and 0.733 , respectively. Furthermore, the $\lambda$ values for the 2 GSCM indicators are 1.164 and 1,000 , with the AVE and C.R values for the GSCM variable being 1.177 and 0.824 , respectively. The value of $\lambda$ in the 2 market uncertainty indicators is 1.524 and 1,000, with the AVE and C.R values for the GSCM variable being 1.661 and 0.864 , respectively. Finally, the test results show that the values of $\lambda$ in the 2 Market uncertainty indicators are 1.119 and 1,000 , with the AVE and C.R values for the GSCM variable being 1.126 and 0.818 , respectively. All of this shows that the indicators used in this study are valid and reliable.

Table 1

Validity and Reliability Test Results

\begin{tabular}{|c|c|c|c|c|c|c|}
\hline Variable & Indicator & $\lambda$ & Validity & AVE & $\mathbf{C R}$ & Reliability \\
\hline \multirow[t]{2}{*}{ Innovation } & I3 & 0,656 & valid & 0,715 & 0,733 & reliable \\
\hline & I6 & 1,000 & valid & & & \\
\hline \multirow[t]{2}{*}{ GSCM } & OPH1 & 1,164 & valid & 1,177 & 0,824 & reliable \\
\hline & OPH5 & 1,000 & valid & & & \\
\hline \multirow[t]{2}{*}{ Market Uncertainty } & TP1 & 1,524 & valid & 1,661 & 0,864 & reliable \\
\hline & TP3 & 1,000 & valid & & & \\
\hline \multirow[t]{2}{*}{ Performance } & $\mathrm{KI}$ & 1,119 & valid & 1,126 & 0,818 & reliable \\
\hline & K4 & 1,000 & valid & & & \\
\hline
\end{tabular}

Table 2

Final Stage SEM Conformity Index

\begin{tabular}{|c|c|c|c|}
\hline Criteria & Cut off value & Results & Note \\
\hline Chi- Square & small & 22,378 & Fit \\
\hline Significance Probability & $\geq 0.05$ & 0.071 & Fit \\
\hline RMSEA & $\leq 0.08$ & 0.063 & Fit \\
\hline GFI & $\geq 0.90$ & 0.967 & Fit \\
\hline AGFI & $\geq 0.90$ & 0.915 & Fit \\
\hline $\mathrm{CMIN} / \mathrm{DF}$ & $\leq 2.00$ & 1.598 & Fit \\
\hline TLI & $\geq 0.95$ & 0.972 & Fit \\
\hline CFI & $\geq 0.95$ & 0.986 & Fit \\
\hline
\end{tabular}




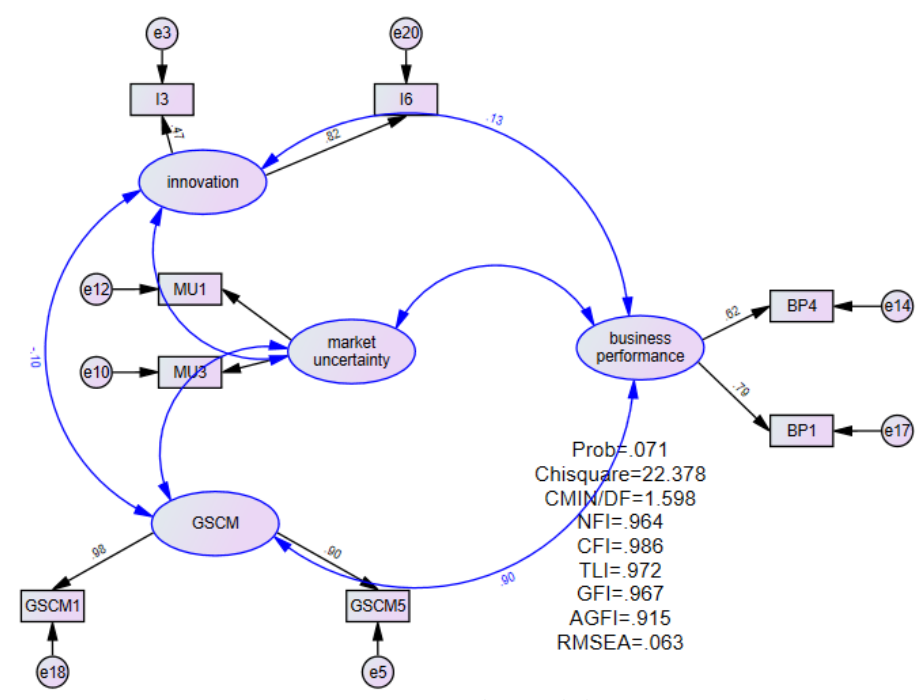

Fig. 1. Research Model

The next test is Goodness-of-Fit (GoF). The test results show the value of Chi-Square of 22,378, Significance Probability of 0.071 (cut-off $\geq 0.05$ ), RMSEA 0.063 ( $\leq 0.08)$, GFI $0.967(\geq 0.900$, AGFI $0.915(\geq 0.90)$, CMIN/DF $1.598(\leq 2.00)$, TLI $0.972(\geq 0.95)$, and CFI $0.986(\geq 0.95)$. This indicates that all indices in the Goodness-of Fit in this study are fit (Table 2; Fig. 1). The last test is hypothesis testing. The test results show that there is a positive and significant influence on innovation and GSCM in the tourism SME sector during Covid-19. These results are indicated by the coefficient value of 0.314, C.R 2.973 and a probability of $0.003(<0.05)$ (Table 3$)$. This confirms that the first hypothesis which states that there is a positive and significant relationship between innovation and market uncertainty in the tourism SME sector is accepted. Furthermore, the test results show that there is a positive and significant influence of innovation on performance in the tourism SME sector during Covid-19. These results are indicated by the value of the coefficient value 0.923, C.R 7.613 and a probability $0.00(<0.05)$. This confirms that the first hypothesis which states that innovation has a positive and significant effect on performance in the tourism SME sector is accepted. The statistical results show that there is a positive and significant relationship between green supply chain management and market uncertainty in the tourism SME sector, with an indication of the coefficient value of 0.547 , C.R 0.284 , C.R 4,915 and a probability of $0.000(<0.05)$. This confirms that the first hypothesis which states that there is a positive and significant relationship between GSCM and market uncertainty in the tourism SME sector is accepted. The statistical output also shows that there is a positive and significant relationship between green supply chain management and performance in the tourism SME sector, with an indication of the coefficient value of 0.284 , C.R.2967 and a probability of $0.003(<0.05)$. This means that the hypothesis which states that green supply chain management has a positive and significant effect on performance in the SME sector is accepted.

Table 3

Hypothesis Testing

\begin{tabular}{lllllll}
\hline Variable & & & Coefficient Value & CR & Probability & Confirmation \\
\hline Market uncertainty & $\leftarrow$ & GSCM & 0.547 & 4.915 & $* * *$ & accepted \\
Market uncertainty & $\leftarrow$ & Innovation & 0.314 & 2.973 & 0.003 & accepted \\
Performance & $\leftarrow$ & GSCM & 0.284 & 2.967 & 0.003 & accepted \\
Performance & $\leftarrow$ & Innovation & 0.923 & 7.613 & $* * *$ & accepted \\
Performance & $\leftarrow$ & Market uncertainty & -0.258 & -2.382 & 0.017 & accepted \\
\hline
\end{tabular}

Finally, the test results regarding the influence of market uncertainty on SMEs in the tourism sector during Covid-19 show a coefficient value of -0.258 , C.R -2.382 , and a p-value of 0.017 . This means that the hypothesis that market uncertainty reduces performance in the SME sector is accepted. This is most likely due to the widespread impact of Covid-19, and was not anticipated by SMEs. Social restrictions have significantly reduced the performance of tourism businesses. In this case, the market uncertainty caused by Covid-19 has a negative effect on the performance of SMEs. The magnitude of the influence that shows a significant effect indicates that market uncertainty has a significant effect on decreasing performance, and is not an accelerator for improved performance. This finding is in accordance with Amri (2020) who suggested that to build new ecosystems and business models in the current digital era, competitive advantage is created from our attachment to the industrial ecosystem which directly changes market orientation and competition, and moves customers to developing online markets digital strategy requires offline and online operating system integration readiness. In the context of innovation, identify the company's need for change, prepare for change. The company's DNA must be designed in such a way as to accommodate customers' social digital needs, especially in times of uncertainty due to Covid-19. Rakhmawati et al. (2019) stated that the higher the strategic orientation of a company, the higher the implications of GSCM. In practical terms, it is recommended to refocus the synergy of support for MSMEs, the development of adequate communication 
infrastructure to support the digitization of SMEs, encourage integrated market access and various financial sources. Furthermore, during a pandemic, programs that are urgently needed during a pandemic are increasing the digital capabilities of human resources, internet accessibility, and the ease of marketing goods in the offline market. Furthermore, during the economic recovery period the required programs underwent changes; Now, training and assistance in business bookkeeping is urgently needed, with marketing programs and enhancing digital capabilities for SMEs. Conceptually, these findings emphasize the importance of relationships between stakeholders and management, between top management and managers below them in a corporate organization which includes management views, differences in organizational culture and leadership in achieving common goals without hindering each other's interests (Davis et al., 1997).

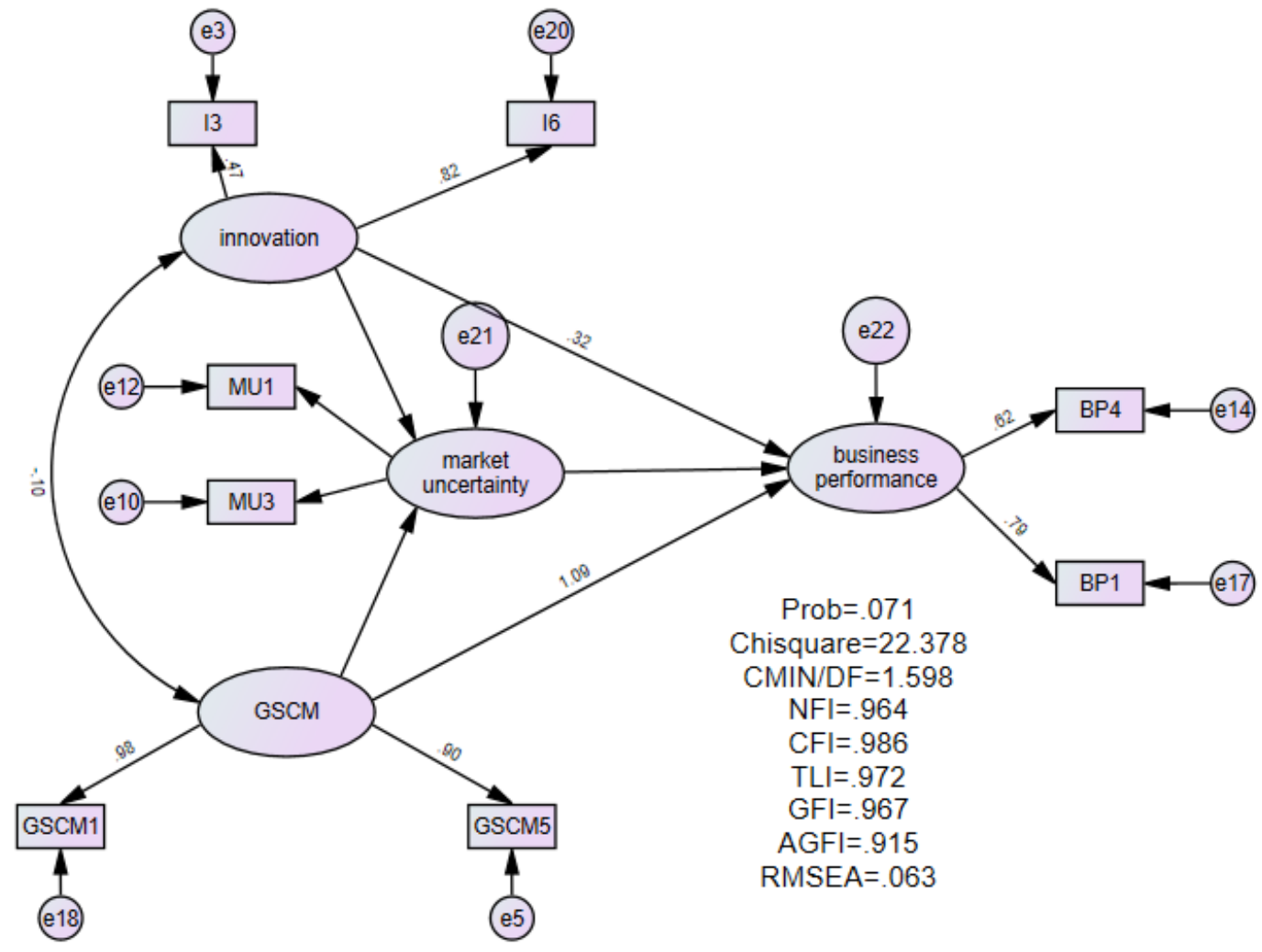

Fig. 2. Full Model
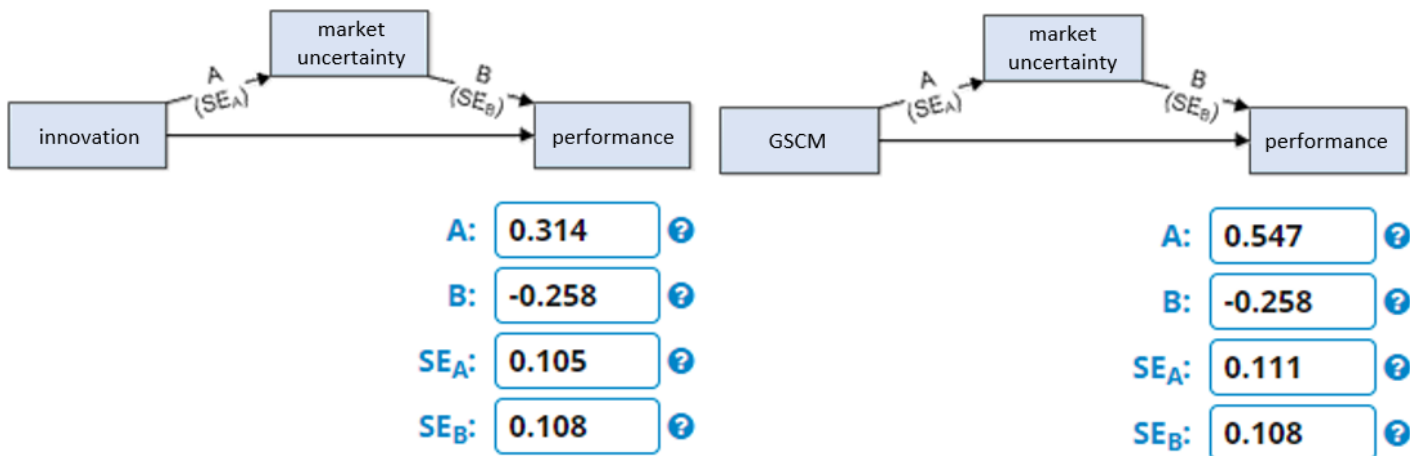

Calculatel

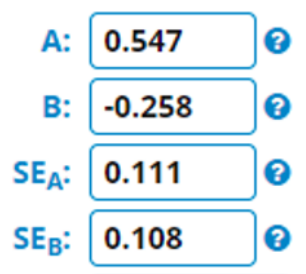

Calculatel

Sobel test statistic: $\mathbf{- 1 . 8 6 6 4 7 1 5 4}$

Sobel test statistic: $\mathbf{- 2 . 1 4 9 6 2 6 0 4}$

One-tailed probability: $\mathbf{0 . 0 3 0 9 8 7 7 1}$

One-tailed probability: $\mathbf{0 . 0 1 5 7 9 2 4 0}$

Two-tailed probability: 0.06197542

Two-tailed probability: $\mathbf{0 . 0 3 1 5 8 4 8 1}$

Fig. 3. Sobel Test for Mediation Effect of Market Uncertainty 


\section{Conclusion}

Based on the research objectives to examine the extent to which market uncertainty can drive market players, this study finds several analyzes related to SME innovation during the Covid-19 pandemic, especially related to efforts to exploit innovation and environmentally friendly orientation to improve their performance. Specifically, the results show that there is a positive and significant influence between innovation and green orientation on SME performance, and the mediating effect of market uncertainty to increase marketing innovation and environmentally friendly orientation. These findings theoretically contribute to explaining the relationship between supply chain management in the context of market uncertainty. In practical terms, this study confirms the need for support by stakeholders to support limited domestic tourism, according to health protocols, as well as digitalization of marketing for tourism SMEs. The study results suggest that from a supply chain perspective, market uncertainty caused by the Covid-19 pandemic has great potential to reduce performance and disrupt production and distribution lines as well as consumer demand. In practical terms, this affects SMEs, such as SMEs that focus on providing tourism products, such as fashion and merchandise, to maintain their performance with product innovation, and minimize the use of non-environmentally friendly products. Conceptually, this study shows that market uncertainty serves as a catalyst for SMEs to maintain performance through marketing innovation and product reorientation. The results show that market uncertainty serves as a catalyst for MSMEs in Yogyakarta to maintain performance through increased marketing innovation and creativity in utilizing green supply chain management. In addition, in the covid-19 pandemic, business actors must optimize the role of human resources, especially increasing their power of innovation and creativity so that this business continues.

\section{References}

Amri, A. (2020). Dampak covid-19 terhadap UMKM di Indonesia. Brand Jurnal Ilmiah Manajemen Pemasaran, 2(1), 123131.

Chang, J., Bai, X., \& Li, J. J. (2015). The influence of leadership on product and process innovations in China: The contingent role of knowledge acquisition capability. Industrial Marketing Management, 50, 18-29.

Dama, J., \& Ogi, I. W. (2018). Pengaruh Inovasi Terhadap Dan Kreativitas Terhadap Kinerja Karyawan Pada PT Bank Mandiri (Persero) Tbk. Manado. Jurnal Emba: Jurnal Riset Ekonomi, Manajemen, Bisnis dan Akuntansi, 6(1).

Darwanto, D. (2013). Peningkatan Daya Saing Umkm Berbasis Inovasi dan Kreativitas (Strategi Penguatan Property Right terhadap Inovasi dan Kreativitas). Jurnal Bisnis dan Ekonomi, 20(2), 24200.

D'Avanzo, R., Von Lewinski, H., \& Van Wassenhove, L. N. (2003). The link between supply chain and financial performance. Supply Chain Management Review, 7(6), 40-47.

Davis, J. H., Schoorman, F. D., \& Donaldson, L. (1997). Toward a stewardship theory of management. Academy of Management review, 22(1), 20-47.

Ellinger, E. P., Lomnicka, E., \& Hare, C. (2011). Ellinger's Modern banking law. Oxford University Press.

Fortuna, I. F., Suamtri, Y., \& Yuniarti, R. (2014). Perancangan Sistem Pengukuran Kinerja Aktivitas Green Supply Chain Management (Gscm) (Studi Kasus: Kud "Batu”. Jurnal Rekayasa dan Manajemen Sistem Industri, 2(3), p551-562.

Gitman, L. J., \& Zutter, C. J. (2012). Principles of Managerial Finance (ed.). Edinburgh, England: Pearson.

Hadiyati, E. (2011). Kreativitas dan inovasi berpengaruh terhadap kewirausahaan usaha kecil. Jurnal Manajemen Dan Kewirausahaan (Journal of Management and Entrepreneurship), 13(1), 8-16.

Hatani, L. (2000). Pengaruh Orientasi Pasar Terhadap Kinerja Pemasaran di Kabupaten Muna. Jurnal Manajemen Unhalu.

Irham, F. (2011). Manajemen kinerja teori dan aplikasi. Bandung: Alfabeta.

Keeh, H. T., \& Nguyen, M. Ping., 2007. The Effect of Entrepreneurial Orientation and Marketing Information on The Performance of SMEs, 592-611.

Kementerian PPN/Bappenas. (2020). Kajian Kebijakan Penanggulangan Dampak Covid-19 terhadap UMKM Survei Kebutuhan Pemulihan Usaha Bagi UMKM Indonesia. Available: https://aptika.kominfo.go.id/wpcontent/uploads/2020/12/BAPPENAS-Penanggulangan-Dampak-Covid-19-terhadap-UMKM-Final-v1_0.pdf.

Laari, S., Töyli, J., Solakivi, T., \& Ojala, L. (2016). Firm performance and customer-driven green supply chain management. Journal of Cleaner Production, 112, 1960-1970.

Larsen, P., \& Lewis, A. (2007). How award-winning SMEs manage the barriers to innovation. Creativity and innovation management, $16(2), 142-151$.

Le Roy, F., \& Czakon, W. (2016). Managing coopetition: the missing link between strategy and performance. Industrial Marketing Management, 53(1), 3-6.

Mulyadi, M. S. (2001). Akuntansi Manajemen: Konsep, Manfaat, dan Rekayasa. $3^{\text {rd }}$ ed. Jakarta: Salemba Empat.

Nasir, A. (2017). Pengaruh Inovasi Produk terhadap Kinerja Pemasaran Industri Mebel di Kabupaten Pasuruan. Referensi: Jurnal Ilmu Manajemen dan Akuntansi, 5(1), 20-25.

Ninlawan, C., Seksan, P., Tossapol, K., \& Pilada, W. (2010, March). The implementation of green supply chain management practices in electronics industry. In World Congress on Engineering 2012. July 4-6, 2012. London, UK. (Vol. 2182, pp. 1563-1568). International Association of Engineers.

Priyono, A. (2009). Pengaruh Praktek Green Supply Chain Management Terhadap Kinerja Perusahaan Dengan Peraturan Pemerintah Sebagai Variabel Moderasi. Jurnal Aplikasi Bisnis, 8(1), 1-12.

Rakhmawati, A., Rahardjo, K., \& Kusumawati, A. (2019). Faktor Anteseden dan Konsekuensi Green Supply Chain Management. Jurnal Sistem Informasi Bisnis, 9(1), 1. 
Render, B., \& Heizer, J. (2005). Manajemen Operasi. Jakarta: Salemba Empat.

Rosita, R. (2020). Pengaruh Pandemi Covid-19 Terhadap Umkm Di Indonesia. Jurnal Lentera Bisnis, 9(2), 109-120.

Rosmadi, M. L. N. (2021). Inovasi dan Kreativitas Pelaku Usaha Umkm di Era Covid-19. IKRA-ITH EKONOMIKA, 4(2), 87-94.

Safitri, F. N. (Kumparan, 2020). Dampak Covid-19 terhadap Usaha Mikro Kecil Menengah (UMKM) di Indonesia. Available at https://kumparan.com/faridanursafitri19/dampak-covid-19-terhadap-usaha-mikro-kecil-menengah-umkmdi-indonesia-1urxzc2LBXH/full

Satria, D. (2011). Strategi Pengembangan Industri Kreatif untuk Meningkatkan Daya Saing Pelaku Ekonomi Lokal. Jurnal Aplikasi Manajemen, 9(1), 301-308.

Savita, K. S., Dominic, P. D. D., \& Ramayah, T. (2016, August). An insight on survey questionnaire design for Green SCM: Using cognitive interviewing method. In 2016 3rd International Conference on Computer and Information Sciences (Iccoins) (pp. 673-678). IEEE.

Setiawan, A., Mulyati, H., and Suroso, A.I. (2011). Kerangka Pengukuran Kinerja pada Green Supply Chain Management. In Orange Book 3 Green Economy Menuju Pembangunan Berkelanjutan. Bogor: IPB Press.

Sherlin, I. (2016). Pengaruh Inovasi Produk Dan Kinerja Pemasaran Terhadap Keunggulan Bersaing (Studi Kasus Industri Kecil Dan Menengah Batik Kerinci). Jurnal Benefita, 1(3), 105-112.

Stefanelli, N. O., Jabbour, C. J. C., \& de Sousa Jabbour, A. B. L. (2014). Green supply chain management and environmental performance of firms in the bioenergy sector in Brazil: An exploratory survey. Energy Policy, 75, 312-315.

Sudiyatno, B., \& Puspitasari, E. (2010). Tobin's q dan altman z-score sebagai indikator pengukuran kinerja perusahaan. Kajian Akuntansi, 2(1), 247233.

Suendro, G. (2010). Analisis pengaruh inovasi produk melalui kinerja pemasaran untuk mencapai keunggulan bersaing berkelanjutan (Studi Kasus Pada Industri Kecil dan Menengah Batik Pekalongan). Jurnal Sains Pemasaran Indonesia (Indonesian Journal of Marketing Science), 10(3), 317-326.

Syamsudin, M. (NU Online, 2020). Dampak Pandemi Covid-19 terhadap UMKM di Indonesia. Available at https://www.nu.or.id/post/read/123247/dampak-pandemi-covid-19-terhadap-umkm-di-indonesia

Wheelen, T. L., Hunger, J. D., Hoffman, A. N., \& Bamford, C. E. (2017). Strategic management and business policy (p. 55). Boston, MA: pearson.

Wibowo, W. (2014). Manajemen Kinerja (Edisi Keenam). Jakarta: Jakarta: Rajawali Pers.

Wright, P. D., Liberatore, M. J., \& Nydick, R. L. (2006). A survey of operations research models and applications in homeland security. Interfaces, 36(6), 514-529.

Wulandari, A. (2012). Pengaruh Orientasi Pelanggan, Orientasi Pesaing dan Inovasi Produk terhadap Kinerja Pemasaran. Management Analysis Journal, 1(2).

Younis, H., Sundarakani, B., \& Vel, P. (2016), The impact of implementing green supply chain management practices on corporate performance. Competitiveness Review, 26(3), 216-245. https://doi.org/10.1108/CR-04-2015-0024.

Yunal, V. O. (2013). Analisa pengaruh motivasi berwirausaha dan inovasi produk terhadap pertumbuhan usaha kerajinan gerabah di Lombok Barat. Agora, 1(1), 337-347.

Zhu, Q., \& Sarkis, J. (2007). The moderating effects of institutional pressures on emergent green supply chain practices and performance. International Journal of Production Research, 45(18-19), 4333-4355.

Zhu, Q., Feng, Y., \& Choi, S. B. (2017). The role of customer relational governance in environmental and economic performance improvement through green supply chain management. Journal of Cleaner Production, 155, 46-53.

Zhu, Q., Sarkis, J., \& Lai, K. H. (2008). Green supply chain management implications for "closing the loop". Transportation Research Part E: Logistics and Transportation Review, 44(1), 1-18.

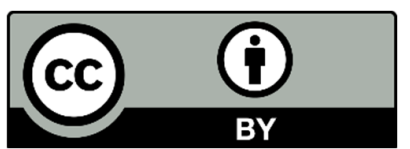

(C) 2021 by the authors; licensee Growing Science, Canada. This is an open access article distributed under the terms and conditions of the Creative Commons Attribution (CC-BY) license (http://creativecommons.org/licenses/by/4.0/). 